\title{
THE BALTIC STATES OF THE THREE SEAS INITIATIVE: ESTONIA, LATVIA AND LITHUANIA IN CREATIVE RELATIONS WITH THE UNITED ARAB EMIRATES
}

\author{
Adam KRZYMOWSKI \\ Department of International Studies, College of Humanities and Social Sciences, Zayed University, \\ P. O. Box 144534, Abu Dhabi, United Arab Emirates
}

Received 6 November 2020; accepted 30 June 2021

\begin{abstract}
The presented manuscript deals with three Baltic states (Estonia, Latvia, and Lithuania) that are part of the Three Seas Initiative in the context of cooperation with the United Arab Emirates. The research's goal is analysis the larger dimension of Three Seas Initiative and its creative role and importance in the international arena, including the Middle East. In this sense, this paper asks a research question of whether the relations between Estonia, Latvia, Lithuania, and the United Arab Emirates have the potential for deeper and broader creative dynamics of their cooperation. The presented article is the first research work of this type. Thus, it fills a gap in the literature and analyses concerning relations between the Baltic states and the United Arab Emirates. This work is primarily base on empirical research conducted for ten years. In addition, the author used his own creative experience, including as an Ambassador to the United Arab Emirates (2011-2015) or Senior advisor at Expo 2020 (2016-2018), responsible for strategies and creative development of relations the United Arab Emirates with all the Three Seas Initiative countries, including Baltic states. As a result of the research, the author argues that Estonia, Latvia, and Lithuania, as a part of the Three Seas Initiative, should make this concept more creative in its external dimension, with the United Arab Emirates. Expo 2020 (1 October, 2021-31 March, 2022) provides an opportunity for creative diplomacy. This event is an occasion to demonstrate joint projects, also in global aspects.
\end{abstract}

Keywords: Baltic states, creative diplomacy, Estonia, Latvia, Lithuania, Three Seas Initiative, United Arab Emirates.

\section{Introduction}

Cooperation between Estonia, Latvia, and Lithuania has special meaning. Even before the declaration of independence of states (from the Soviet Union), on 12 May, 1990, in Tallinn, Estonia, these countries signed the Declaration on Unity and Cooperation by the Republic of Estonia, Republic of Latvia and Republic of Lithuania, constituting institutionalized relations. On 8 November, 1991, partners established the Baltic Assembly as a platform for interparliamentary cooperation. Its statute entered into force on 31 October, 1993. Prime ministers on

*Corresponding author. E-mail: ak7@vp.pl

Copyright (c) 2022 The Author(s). Published by Vilnius Gediminas Technical University

This is an Open Access article distributed under the terms of the Creative Commons Attribution License (http://creativecommons. org/licenses/by/4.0/), which permits unrestricted use, distribution, and reproduction in any medium, provided the original author and source are credited. 
13 June, 1994, in Tallinn, signed the Agreement on Baltic Parliamentary and Governmental Cooperation between the Republic of Estonia, the Republic of Latvia and the Republic of Lithuania. As a result, they set up the Baltic Council of Ministers. The newly established framework for cooperation facilitated mutually support each other in the new geostrategic situation, especially in the integration with North Atlantic Treaty Organization (NATO) and the European Union (EU). In 2004 strategic goals have been achieved. Leaders have started searching for new goals related to the role and importance of the Baltic states. Therefore, on 3 June, 2010, in Lithuania, prime ministers adopted the Vilnius Declaration titled A Vision of the Baltic Sea Region by 2020. In the period 2020-2021, Lithuania holds the Presidency at the Council of the Baltic Sea States. Its priority goal is sustainable development. In addition, discussions began on the Vilnius Declaration A Vision of the Baltic Sea Region until 2030. In the current globalized international relations, it is necessary to go beyond established patterns and be creatively active.

Given the new dynamics of international relations, including in the European integration processes, the global security architecture, the Three Seas Initiative (3SI) launched in 2015 is of particular importance. Twelve participant countries by joint creative activities have a chance to influence the EU projects. Additionally, due to its location, amidst the three seas (Baltic Sea, Black Sea, Adriatic Sea), they have an opportunity to co-shape the international environment, including the Middle East and North Africa (MENA). Therefore, relations with the United Arab Emirates (UAE), the most active Gulf Cooperation Council (GCC) state, take on a strategic dimension.

The research problem is the dynamics of the three Baltic states' (Estonia, Latvia, Lithuania) creative relationship with the UAE. Therefore, the research goal is to present the consequence of these activities and their effects on the innovation potential. Estonia and the UAE have an opportunity to develop information technology (IT) and artificial intelligence (AI). Latvia can provide agriculture, pharmacology projects for the UAE. While Lithuania can have specialised cooperation in the field of laser technology and solar panels. Moreover, the presented manuscript aims to find an answer to the research question of whether the relations of the three countries of the Baltic region with the UAE have the potential for deeper and broader dynamics of their creative development with the impact on the implementation of the 3SI and the Middle East. For this purpose, this research study primarily used empirical research conducted by the author for ten years. Additionally, in this period, the author creatively participated in many projects, initiatives related to the UAE and the 3SI countries. The researcher conducted creative diplomacy as an Ambassador, Senior advisor at Expo 2020. This paper is the first publication analysing the Baltic states and the UAE.

In the presented research, the author is trying to defend a statement that these countries by initiating a few years ago creative cooperation with the UAE have a great occasion to become more significant actors in the international arena. However, one of the conditions for achieving this goal is to increase the attractiveness of its potential by being creatively connected with 3SI projects. The research paper analyses the creative diplomatic activities, first, at the level of Heads of states, Ministers, experts, Parliament members. The importance of research on creativity is emphasized by Rothenberg and Hausman (1976, p. 5). They claim that creativity is key to development and even to survive in the face of new challenges, in which old patterns of 
understanding and acting are insufficient or inadequate. According to Jung (2014, pp. 61-62), the concept of creativity refers to potential, opening new perspectives, and creating new opportunities. Moreover, the implementation of creative concepts leads to innovation. Therefore, creativity can be measured based on the implemented ideas, strategies, or plans. Many actors in international relations adopt creative strategies. The EU (Council of the European Union, 2019) develops concepts for the creative dimension of the international relations of the EU and its member states by strengthening cross-sectoral cooperation between and within the EU's institutions and the member states. The author of the presented article defines the relationship between the UAE and Estonia, Latvia, Lithuania as creative since 2015. Their fundamental determinant is the proactive nature of the relationship between them, rather than being reactive. Consequently, the researcher measured the creativity of these states of foreign policies through examining the government visits, initiatives, and projects.

\section{Literature review}

This manuscript resulted from the author's experience and conducting scientific analysis in the presented area. Some of the papers are important for an answer to the research question of this article. In the manuscript "The European Union and the United Arab Emirates as Civilian and Soft Powers Engaged in Sustainable Development Goals” (Krzymowski, 2020c), the researcher demonstrates the UAE's significance for the EU. The author analyses increasing dynamics of relations to boost both actors' influence on a global arena. In the research paper titled "Sustainable Development Goals in Arab Region - United Arab Emirates' Case Study" (Krzymowski, 2020b), the researcher shows the UAE's creative strategies, and policies to achieve an innovative economy. Analysing the UAE, the National Innovation Strategy, the Green Economy initiative, the Energy 2050 Strategy, the paper indicates an opportunity for creative relations with this country. Moreover, in the article "Expo 2020 Dubai on the Journey to Achieve the United Arab Emirates' Soft Superpower" (Krzymowski, 2020a), the author presents the World fair, Expo 2020 as a creative instrument of the UAE Soft Power Strategy (SPS). It is a chance to develop creative international relations. In another manuscript titled "The Significance of the Black Sea Countries of the Three Seas Initiative Relations with the United Arab Emirates" (Krzymowski, 2020e), the researcher focuses on the UAE and Central and Eastern Europe cooperation, especially with Bulgaria and Romania. However, the author indicates that it essential for the 3SI, including for the Baltic states. Therefore, in the article "The Importance of Ukraine's Political and Economic Relationship with the United Arab Emirates for the Lublin Triangle" (Krzymowski, 2020d), consequently, the researcher presents projects, and opportunities for creative cooperation between the UAE and Lithuania, Poland, Ukraine. The author argues that the UAE could become a creative partner for the new, innovative concept of the Lublin Triangle.

Regarding Estonia's foreign and security policy, Raik (2020) in a study titled Estonia in the UN Security Council: The Importance and Limits of European Cooperation emphasizes that Estonia's strategic interest is an engagement to develop durable transatlantic relations. Moreover, the author underlines that the EU has to become more effective in resolving international conflicts, especially in its neighbourhood. On the other hand, Maigre (2015) in 
"Estonia: In Pursuit of a Value-Based Foreign Policy" notes that although NATO is fundamental to Estonia's foreign and defence policy, this country is concerned about the security of the Baltic region. The researcher also shows the significance of the conflict between Russia and Ukraine for the Euro-Atlantic security structures.

Analysing Latvia's foreign and security policy, one should note the Milevski's (2020) publication titled "Latvia's New State Defense Concept". The author presents the latest concept of state defence, adopted in June, 2020. The document demonstrates a geopolitical assessment. It highlights increasing challenges facing the global security architecture due to the acceleration of complex diplomacy and economic relations. Rostoks (2020) in the analysis titled "Global Processes and Latvian Foreign Policy in 2019", emphasizes that Latvia has limited possibilities of influencing international relations in the Middle East. However, they have an impact on Latvia. Therefore, the country should be active in this region and pursue its interests. On the other hand, Broka (2021) draws attention to the normalization of relations, and cooperation in the field of security and economic projects between Israel and the UAE, which initiated a new regional order. The author emphasizes that 2020 was the most dynamic period in the history of relations between Latvia and the Arabian Gulf. Due to the World's fair in Dubai, UAE, 2021 will be a time of growing Latvia's engagement with this region, especially the UAE.

Regarding Lithuania, Nekrašas (2011) in the publication "Reflections on Lithuanian Foreign Policy" describe and assess this country's external relations. The author emphasizes Vilnius', Lithuania strategic choice of integration with Euro-Atlantic structures. Paulauskas (2004) in the article "Lithuania's New Foreign Policy" presents the new geopolitical situation Lithuania has found itself in after it acceded to the EU and NATO. The author shows Vilnius' greater responsibility as a member of key organizations for the transatlantic community. In this context, he also examines the activity of Lithuania in the Middle East. Hyndle-Hussein (2020) in the publication "Litwa: profil rządu Ingridy Šimonytë" analyses the new program of Government of Lithuania. The author emphasizes that Vilnius will pursue a more dynamic foreign and security policy at the arena global of international relations. Lithuania intends to be active in the EU's actions towards the MENA. Jakniūnaite (2018), in the article "No Good End in Sight: The Crumbling Iran Nuclear Deal", argues that Lithuania's foreign and security policy faces new challenges. It results from the tensions in the transatlantic relations, in recent years, and the instability in the Middle East. On the other hand, Lingevicius (2020) in the research "Identity Discourse within a Geopolitical Crisis: The Case of Lithuania" points out that the annexation of the Crimean Peninsula in 2014 has impacted on starting a new stage of the creative search for new directions in Lithuania's foreign and security policy.

Analysing the literature on Estonia's, Latvia's, and Lithuania's foreign policies, it should be noted that there are no studies on the relations of these countries with the UAE. Therefore, this research fills this gap. The presented article can be a valuable analysis for international relations researchers and practitioners, including diplomats.

\section{Theoretical framework and research methodology}

This research work applied foreign policy analysis (FPA) as an appropriate analytical tool to study the creative cooperation between the UAE and three Baltic states belonging to the 
3SI. As emphasized by Gerner (1995, p. 17) or Smith et al. (2016, p. 4), a foreign policy still is based on the sciences of international relations. Gerner (1991, p. 125) notes that many researchers identify FPA, referring not only to general knowledge but also to historical and normative studies. Introductions to the FPA are provided, among others, by Breuning (2007), Hudson (2007), and Smith (1983). Research conducted by Snyder et al. (1962) is key to the development of FPA. In the United States (US), customary referring to foreign policy theories relating to factors at the domestic level as "foreign policy analysis" (Hudson, 2007, p. 17). However, Gerner (1991, p. 123) argues that the foreign policy analysis should focus on the domestic level constituents and the international one. Smith (1986, p. 17) emphasized that a comprehensive foreign policy theory can be created only by combining factors from the national and international areas. Such a combination of the two levels of foreign policy analysis was presented by, among others, Hudson (2007) and Putnam (1988). Moreover, as Neack et al. (1995) emphasize, to understand and explain the processes of foreign policy and the behaviour of its participants in the international system, it is necessary to combine a variety of measures and actions. Gerner (1995) emphasizes that actors' intentions, statements, activities, and the reactions to them by other players, there are crucial for FPA. Therefore, when analysing foreign policy, should be examined both the international environment and internal conditions. FPA is at the intersection of theoretical knowledge about external affairs with the practice of international political life. It aims to organize the information that allows a choice of the most significant elements and learning about the correlations between them.

When analysing research on international relations, counting FPA, it should be noted that the creativity issue is still rarely present in them. An orderly understanding of it is still lacking. However, as Kodabux (2019) points out, international relations researchers, including FPA supporters, should increasingly recognize the need for creativity. It is a condition for this science to continue to develop. At the same time, more and more players in the international arena are implementing creative strategies and operational activities. The reason is the interconnected world and the enormous dynamics of events occurring in it. It often requires non-standard, creative plans and actions. An interesting example of creativity in foreign policy is provided by the so-called Kevin Rudd factor. As the head of Government, he conceptualized and presented his foreign policy paradigm as "middle-level creative diplomacy". Creativity was about wanting to restore energy and redefine foreign policy into a proactive global commitment. In just a few months, Rudd showed tremendous dynamics in foreign visits to give credibility to a new, creative foreign policy. The condition for its success was new global challenges recognition with the proactivity (Baba \& Kaya, 2014). One should agree with Kodabux (2019) that creativity provides fresh, new horizons. It delivers an opportunity to discover possibilities and realities that have not been considered before. Thus, creativity opens a better potential for generating expanded knowledge as it shows a broader picture of the various possibilities. Creativity relates primarily to the leadership of middle powers that exert an influence on other participants in international relations by the force of ideas (Evans \& Grant, 1991, p. 325). However, one should also agree with Katzenstein (1985) that small states, being more flexible, have broader potential to be more creative in foreign policy.

The applied theory helps to understand the selected research area and the phenomena taking place in it. Moreover, it facilitates finding an answer to the research question. However, 
the adopted theory is based on some axiomatic assumptions. Therefore, the FPA and its theoretical arguments were tested in the presented research using the case study method. Each of the three countries separately, Estonia, Latvia, and Lithuania were analysed in relation to the UAE. The author collected research material, information primarily from governmental institutions of the examined countries. Then, these documents became the subject of analysis, critical evaluation, and comparison. The main reason for conducting this research with this type of information source is the lack of studies on relations between the Baltic states and the UAE in the subject literature. In addition, the author of the presented article had the opportunity to verify the information through personal participation and the possibility of direct observation of the processes taking place in the creative development of the UAE's relations with Estonia, Latvia, Lithuania. Therefore, the adopted research methods in conjunction with the author's experience and direct participation in the analysed phenomena, contribute to the development of science and the discussed research area.

FPA has a sub-domain that includes different questions and analysis levels and an appropriately diverse set of methodological approaches. The author of the article, placing particular emphasis on case study methodologies, applied qualitative analysis. To make the case studies relevant to the development of the existing knowledge, the researcher used methods to obtain original qualitative data. These are archival research, content analysis, interviews, and focus groups (Potter, 2017). However, when using content analysis, the author also used the methodology of interpretative. Defining criteria in recognizing a given reality is a fundamental methodological element. Therefore, the author has adopted several analysis criteria. One of them is the subjective criterion. The research investigates three Baltic states and one Middle East state. The second criteria are objective. It includes analyses of political, economic, and military relations. Another criterion is the time perspective. The author presents the historical background of establishing diplomatic relations between the studied countries. However, a detailed analysis of the last few years shows the potential for the dynamic development of creative relationships.

\section{National strategies and expectations}

On 1 January, 2020, Estonia became a non-permanent member of the United Nations Security Council (UNSC). In the first months, the Israeli-Palestinian Peace Process was one of the priorities (Raik, 2020, p. 2). At the beginning of the new Estonian role in the United Nations, many countries, also the High Representative of the EU for Foreign Affairs and Security Policy Josep Borrell criticized the initiative presented by the US to resolve the Israeli-Palestinian conflict. Despite this situation, Estonia supported the American proposal (Raik, 2020, p. 6). In 2020, for the first time, was presented a comprehensive strategy for Estonia's foreign policy until 2030. This country's foundation of foreign and security policy is its activity in the EU and NATO. However, the Government's priority is also to increase Estonia's global activity, implementing creative diplomacy. They want to realize this plan by including involvement in new international initiatives, supporting multilateral diplomacy. Tallinn identifies the fulfilment of the Sustainable Development Goals as a strategic goal. Also, this country supports a new US peace initiative in the Middle East. Estonia's main point of foreign policy in 2020 
was the summit of the 3SI organized in June in Tallinn. Moreover, they have wanted to accelerate the implementation of the 3SI creative projects. The Government of Estonia (GE) is determined to develop the 3SI (The Baltic Course: International Magazine for Decision Makers, 2020). To this end, the foreign policy strategy emphasizes the need to attract investors from outside the region. Therefore, the Government has decided to strengthen the presence of economic diplomacy in Abu Dhabi, UAE (Republic of Estonia, Ministry of Foreign Affairs, 2020). Diplomatic relations between Estonia and the UAE concluded in March, 2006. However, still there is no UEA diplomatic mission in Estonia. The UAE Ambassador residing in Stockholm, Sweden has additional accreditation in Estonia. In contrast, Estonia in June, 2019 established an Embassy in Abu Dhabi.

At the beginning of June, 2020, Latvia presented to the public a new State Defence Concept. This document defines the strategic goals and instruments of security and defence policy for the coming four years. The strategy identifies changes in the global security architecture. However, it focuses primarily on the immediate international environment and the increase security challenge for the Baltic region. To this end, a boosted number of military exercises is to take place. Regardless of its armed forces, as the foundation of the state's defence, Latvia wants to develop allied cooperation within NATO and the EU. However, the US will remain a key security and defence partner. Therefore, it was decided to expand and raise the standard of the existing critical infrastructure for the effective support and presence of US troops and other allies, including Poland. Latvia's declaration on opening for cooperation in the field of security and defence with countries outside the NATO is also worth noting (Milevski, 2020). The Baltic states should be creative in their perception of 3SI and not just limit themselves to Europe or the US. In this context, the UAE, as a partner outside the North Atlantic alliance, and at the same time with close, also institutional relations with NATO, appears as an interesting creative ally, especially in ensuring the US' strategic balance between Central and Eastern Europe and the Middle East (Milevski, 2020). Riga, Latvia is in favour of a peaceful settlement of conflicts in the Middle East. From the point of view of Latvia's security interests, the priority issue is to develop the American military presence in the Baltic region (Rostoks, 2020, p. 41). Just four weeks after signing on 15 September, 2020 UAE - Israel normalization agreement (Abraham Accords), on 14 October, 2020, a meeting took place between the political director of the Ministry of Foreign Affairs (Latvia), Jānis Mažeiks, the UAE Ambassador Hanan Khalfan Obaid Ali Al Madhani, and the Ambassador of Israel Orli Gil. The Latvian representative expressed an interest in security and stability in the wider Middle East. In this sense, Latvia showed creative diplomacy, demonstrating interest in trilateral cooperation between Latvia, the UAE, and Israel by implementing joint projects (Ministry of Foreign Affairs, Republic of Latvia, 2020).

As proved by the research carried out by Lingevicius (2020, p. 38), the issue of the country's identity in foreign and security policy is subject to dynamic changes taking place both internally and externally. Therefore, this matter is essential for the analysis of foreign policy, the recognition of new challenges, and their trends. These are crucial for decision-making processes in international relations. When discussing the new Lithuanian foreign policy, one should agree with the statement by Nekrašas (2011) that its foundation should be Western, not Eastern dimension. Moreover, in the current globalized challenges, an effective network 
of strategic partners should also be built, going beyond the immediate neighbourhood. On 11 December, 2020, the new Government of Lithuania, headed by Ingrida Šimonyte as Prime Minister, and Gabrielius Landsbergis, the Minister of Foreign Affairs, started. On that same day, the Government program was adopted, which does not envisage main changes, i.e., relying on Euro-Atlantic and regional cooperation. The new Minister of Foreign Affairs declared to strengthen the strategic partnership with the Baltic states, including the improvement of relations with Latvia. Lithuania is ready to dynamize its diplomacy in the international arena. Vilnius intends to be more active in the EU Common Foreign and Security Policy (CFSP), including in the MENA area (Hyndle-Hussein, 2020). Moreover, as declared by the Chancellery of the President of the Republic of Lithuania, as part of the economic diplomat, the new fields of specialization in foreign policy will be presented soon. On 15 January, 2021, a meeting of the Foreign Policy Coordination Council (FPCC) chaired by President Gitanas Nauseda took place. Participants confirmed that the Euro-Atlantic direction is still a pillar for Lithuania's foreign policy. Moreover, the FPCC underlined the idea of the dynamization of Vilnius' participation in the Eastern Partnership. During the closed part of the meeting, they raised issues related to significant Lithuania security interests (The President's Communication Group, 2021). Vilnius identifies Poland as the strategic partner, principally, as the future foundation for deepened cooperation between Central and Eastern Europe and the Scandinavian countries. In turn, it would serve the strategic Nordic-Baltic Cooperation in ensuring an increase of the Baltic region's role and significance (Paulauskas, 2004, p. 14). From security interests for Lithuania, the crucial issue remains the strengthening of the alliance with the US, contributing to increased security in the Baltic region. In the first years of Presidency of Donald Trump, Lithuanian foreign policy planners and strategists perceived the US' activity in the Middle East as an increasing challenge (Jakniūnaitė, 2018, p. 47). However, due to the extensive dynamics of international relations, the Baltic states' policy planners should think out of the box, including establishing a creative agenda with the UAE.

In 2017, the UAE adopted the Soft Power Strategy to coordinate the government and private sector efforts to increase the UAE's global impact, including attracting new cooperation partners. This goal is to be implemented primarily by the active, broadly defined public diplomacy of the UAE (Krzymowski, 2020a, p. 4). In recent years, the UAE has initiated a strategy of intensifying relations with Central and Eastern European countries. UAE demonstrates its attractiveness as a country with great logistic possibilities. In this context, it is essential to emphasize the importance of transport and logistics infrastructure for the 3SI. It is a decisive element of the Baltic states' development strategy and the 3SI's success. Also, its implementation will enable the connection of Europe, the Baltic Sea with the MENA, and the GCC countries, including the UAE (Krzymowski, 2020e, p. 101). Estonia, Latvia, and Lithuania activities outside the EU prefer to coordinate within the EU CFSP and European External Action Service (EEAS). In January, 2018, the UAE Ministry of Foreign Affairs and International Cooperation signed an agreement with the EEAS. The purpose of this agreement is to build strategic cooperation, including in areas such as trade, innovation, research, education, transport, environment, health, consumer protection, and multilateral cooperation (Krzymowski, 2020c, p. 52). 


\section{Findings}

\subsection{Estonia}

Until 2015 two visits took place, only. In June, 2009 UAE Minister of Foreign Affairs and International Cooperation Sheikh Abdullah bin Zayed Al Nahyan came to Estonia. Another visit was of the Estonian counterpart, Urmas Paet, in April, 2011 in the UAE. Relations between countries did not show significant dynamics until 2015. In October, the Prime Minister of Estonia, Taavi Rõivas with a delegation of business representatives visited the UAE. During a conversation with Vice President and Prime Minister of the UAE and Ruler of Dubai, Sheikh Mohammed bin Rashid Al Maktoum both sides agreed to establish close creative strategic cooperation in the field of smart cities as well as IT. Therefore, during the meeting, partners signed the Memorandum of Understanding (MoU) between Dubai Smart Government and the Government of Estonia. The goal of this agreement is the exchange of experiences, information, knowledge, and data in the areas of smart government and smart cities, as well as IT and modern communications. Moreover, both sides agreed to invest in the IT sector for innovation to build a smarter future (Ave Tampere: Government Communication Unit, 2015). As a consequence of creative diplomacy, in August, 2016, a governmental delegation from the UAE Telecommunications and Digital Government Regulatory Authority (TDRA) (2016) came to Estonia to establish expert cooperation. In February, 2017, Minister of Defence, Margus Tsah$\mathrm{kna}$, visited the UAE to negotiate for expanding opportunities for cyber defence cooperation (Republic of Estonia, Ministry of Defence, 2017). In May, 2018, UAE Minister of Economy, Sultan bin Saeed Al Mansoori with the Dubai Chamber of Commerce and Industry's (DCCI) delegation came to Estonia. He met with his counterpart Kadri Simson and Prime Minister Jüri Ratas (WAM, Bashir 2018). In December, 2018, Minister of Entrepreneurship and IT, Rene Tammist visited Dubai to talk about Expo 2020 and prepare creative promotions for Estonian IT companies during this event (Vahtla, 2018). While, in February, 2019, Prime Minister Ratas paid visit in the UAE. During the meeting with the Vice President, Prime Minister of the UAE and Ruler of Dubai, Sheikh Mohammed bin Rashid Al Maktoum, both sides expressed interest in strategic creative cooperation in the field of AI. Additionally, Prime Minister Ratas with the Minister of Entrepreneurship and IT, Tammist opened the Enterprise Estonian representation in Dubai (Government Communication Unit, 2019). In the same year, in September, 2019, the Estonian President Kersti Kaljulaid came to the UAE, with 70 Estonian business representatives. In the era of the digital revolution, the visit's main goal was expanding, and deepening creative cooperation in the IT sector (Salman, 2019). In December, 2019, the Minister of Defence Jüri Luik with the Estonian Defence Industry Association came to the UAE to establish closer cooperation in the field of security (WAM et al., 2019). In February, 2020, the Foreign Affairs Committee of the Parliament of Estonia visited the UAE to strengthen parliamentary relations with the UAE Federal National Council and to implement creative economic diplomacy (Press Releases, Foreign Affairs Committee, 2020).

\subsection{Latvia}

Latvia established diplomatic relations with the UAE on 18 September, 1995. Until 2012, ties between countries were not characterized by a particular dynamic when in March the 
Prime Minister of Latvia, Valdis Dombrovskis arrived in the UAE. Then the first closer rapprochement between the two countries took place. In March, 2014, UAE Minister of Foreign Affairs and International Cooperation, Sheikh Abdullah bin Zayed Al Nahyan came to Latvia, where he met with Latvian President Andris Bērziņš, Prime Minister Laimdota Straujuma, and his counterpart Edgars Rinkēvičs. During the talks, partners focused on joint investments, principally, in the sectors of agriculture, pharmacology, civil aviation, and wood industry and determining the next steps to strengthen relationships (Breitbart, 2014). In the same year, Latvia opened the Embassy in the UAE. Since 2015, the next stage of dynamizing creative relations has taken place. In June, Minister of Foreign Affairs Rinkēvičs arrived in the UAE, where he met, among others, with his counterpart, conducting both political dialogue and discussing ways to strengthen economic relations. During the visit, two Latvia-UAE economic forums were held, both in Abu Dhabi and Dubai (Emirates News Agency, 2015a). At that time, the minister opened the representative office of the Investment and Development Agency of Latvia in Dubai. To pursue common economic interests, in May, 2016 the Deputy Prime Minister and Minister of Economics (Latvia) Arvils Ašeradens came to the UAE, where he met, among others, with UAE Minister of Economy, Sultan bin Saeed Al Mansoori. In addition to talks about delivering new dynamism to creative economic relations, both parties signed an Agreement on Economic and Trade Cooperation. Moreover, in the context of Expo 2020, Minister Ašeradens met with UAE Minister of State for International Cooperation, Reem Al Hashimy (Emirates News Agency, 2016). Consequently, in October of the same year, the second round of political consultations took place (United Arab Emirates Ministry of Foreign Affairs and International Cooperation, 2016). In February, 2017, President Raimonds Vejonis together with ministers and business representatives arrived in the UAE. He invited UAE partners to establish an economic strategy, primarily in areas such as tourism, trade, innovation (Lsm.lv, 2017). That same year, the UAE opened the Embassy in Latvia. In May, 2018, the UAE Minister of Economy, Sultan bin Saeed Al Mansoori came to Latvia. During the visit, he met Prime Minister, Māris Kučinskis, Minister of Foreign Affairs Rinkēvičs. The Latvian side emphasized that the UAE is the most important economic partner in the Gulf area. Partners discussed creative tools for promoting Latvia during Expo 2020. Moreover, both sides agreed that as soon as possible should be the first meeting of the Latvian-UAE Economic Commission (Ministry of Foreign Affairs, Republic of Latvia, 2018). As a consequence of creative activities, less than two weeks later, the DCCI delegation came to Latvia, which met with the President and Prime Minister. Hamad Buamim, President of the DCCI, said that there are five creative areas in which Latvia could achieve significant success in cooperation with the UAE, i.e., agriculture, information and communications technology (ICT), logistics, tourism, and healthcare (Dubai Chamber, 2018).

\subsection{Lithuania}

On 16 October, 1992, the UAE recognized the independent state of Lithuania de jure. On the same day, both states established diplomatic relations. There is no UAE Embassy in Lithuania. The Ambassador of the UAE in Poland is a non-resident Ambassador to Lithuania. Still, there is no Lithuanian Embassy in the UAE. The Ambassador of Lithuania in Egypt is a non-resident Ambassador to the UAE. Until 2012, relations were not characterized by high 
dynamics, when in May the Lithuanian Minister of Foreign Affairs, Audronius Ažubalis came to the UAE. During this visit, apart from talks, both sides signed the first Agreement for Air Services. Another impulse in bilateral creative relations was the visit of the UAE Minister of Foreign Affairs and International Cooperation, Sheikh Abdullah bin Zayed Al Nahyan to Lithuania in June, 2014, where he met with his counterpart Linas Antanas Linkevičius as well as President Dalia Grybauskaite and Prime Minister Algirdas Butkevičius. The discussions were primarily concerned about increasing investment and economic creative cooperation (Emirates News Agency, 2014). The following year, the Lithuanian Minister of Economy, Evaldas Gustas came to the UAE. He met the UAE Minister of Economy, Sultan bin Saeed Al Mansoori. Both sides decided to take quick action to increase the food trade and stimulate investment in this area. Minister Gustas proposed that Lithuania can be a strategic partner in implementing the Emirates food security strategy (Emirates News Agency, 2015b). In July, 2017, another visit by the UAE Minister of Foreign Affairs and International Cooperation, Sheikh Abdullah bin Zayed Al Nahyan took place. During the stay, he met President Grybauskaite, with his counterpart Minister of Foreign Affairs, Linkevičius, and Minister of the Interior (Lithuania), Eimutis Misiūnas, with whom he signed MoU on recognition of driving licenses (United Arab Emirates Ministry of Foreign Affairs and International Cooperation, 2017). Another significant confirmation and impulse for closer relations was the visit of the President of the Republic of Lithuania Grybauskaite with ministers and entrepreneurs at the beginning of November, 2017, during which both parties at the highest level recognized the need for dynamic relationship development (WAM et al., 2017). It was an official visit, which opened a new stage of creative relations. During the meetings, both state leaders agreed on deepening cooperation in trade, energy, including renewable, and innovation, lasers. The President of the Republic of Lithuania proposed cooperation within the Laser Technology Centre at the newly established Masdar Institute of Science and Technology in Abu Dhabi. Additionally, the head of state emphasized that her country has a $10 \%$ share of this sector's global market. In contrast, solar panels manufactured in Lithuania are one of the most efficient products of this kind. Lithuania recognized broader aspects of international relations with innovative and creative projects as a condition for any success. For the UAE, investment in innovative products, especially in the field of renewable energy, is a strategic priority (Krzymowski, 2020b). Therefore, on 1 November, both sides signed an agreement on economic and technical cooperation. In addition, for the first time in Dubai, a business forum between the two countries took place. During this event, partners additionally emphasized the great potential for trade in agricultural products. Regarding the strategic security area, the leaders underlined the need to deepen cooperation in combating terrorism and extremism. At the same time, both sides highlighted that the UAE and Lithuania cooperate in Iraq and Syria within the US-led Operation Inherent Resolve. Also, partners discussed the cooperation of the UAE with NATO and the EU. Lithuania is engaged to o finalized an accepted draft of a free trade agreement between the EU and the GCC. It is also worth noting that both countries support each other in the international arena. For example, Lithuania supported the UAE in winning the right to organize Expo 2020. The UAE, on the other hand, supported Lithuania's request to grant the country the status of a non-permanent member of the UNSC. Another example is mutual support in elections to the United Nations 
Educational, Scientific and Cultural Organization Executive Council (Press Service of the President, 2017). As a consequence of creative activities, in May, 2018, the UAE Minister of Economy came to Lithuania, where he met with President Grybauskaite, Prime Minister Saulius Skvernelis. Both sides decided that Expo 2020 will be a great opportunity to promote Lithuania and pursue its interests. Moreover, partners also agreed to deepen and expand relations in innovative sectors, such as InfoTech, logistics, telecommunications, electronics, and biotechnology (United Arab Emirates Ministry of Foreign Affairs, 2020). In March, 2020, the Minister of Foreign Affairs of Lithuania, Linkevičius paid a visit to the UAE, where together with his counterpart Sheikh Abdullah bin Zayed Al Nahyan inaugurated the functioning of the Lithuanian Embassy in the UAE, which is also the first diplomatic mission in the region. Minister Linkevičius underlined that the UAE is a strategic partner in this part of the world. The opening of the Embassy is an element for further strengthens the joint partnership. It will contribute to the pursuit of common interests (United Arab Emirates Ministry of Foreign Affairs and International Cooperation, 2020). Currently, to realize this idea, it needs creative projects.

\section{Comparison}

The conducted research shows that from 2011 to June 2015, Estonia, Latvia, and Lithuania had a similar level of top-level visits with the UAE. Since July, 2015, Estonia and Lithuania recorded an increase, and Latvia maintained the same level. The chart below is based on the author of this article study, using data from governmental institutions. It shows the dynamics of changes in the most significant official bilateral visits, including visits at the level of heads of state and government, as well as ministers of foreign affairs, the economy, and members of the Royal Family having high state positions (Figure 1).

When analysing the export to the UAE in the last ten years by Estonia, Latvia, and Lithuania, there were similar dynamics. Moreover, combining both parameters, i.e., both top-level

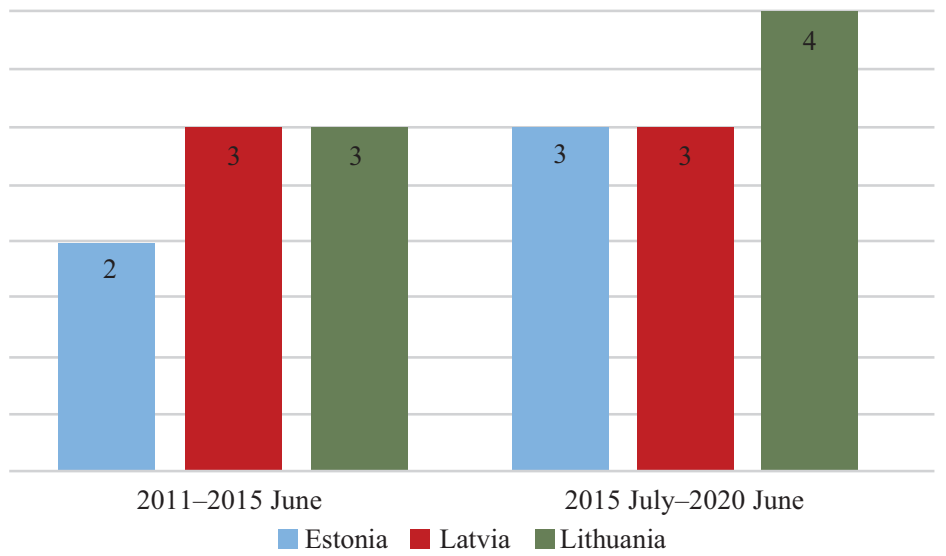

Figure 1. The most significant official bilateral visits (source: created by author) 


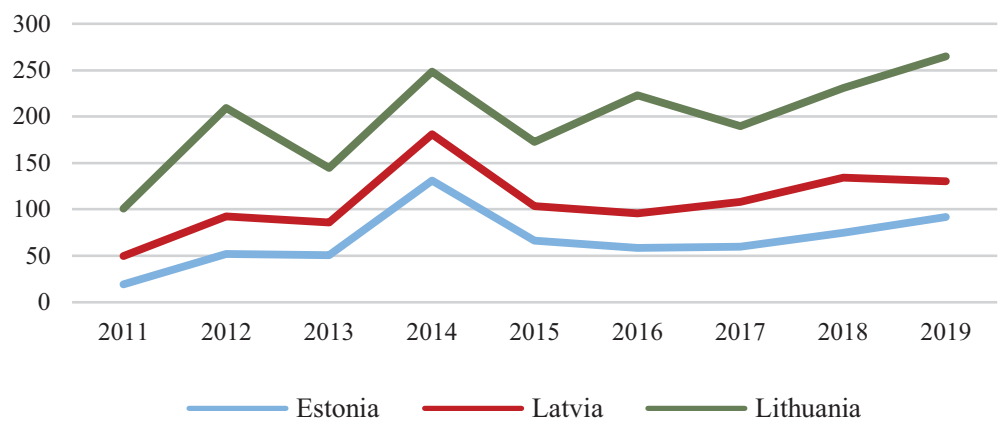

Figure 2. Export to the United Arab Emirates (source: created by author)

visits and the dynamics of trade, it should be stated that there is a high probability that Estonia, Latvia, and Lithuania will be beneficial consistent visits, including economic ones. Only a creative foreign policy and its instruments can provide new opportunities and prospects for a state. The chart below based on the author's study, using data from governmental institutions. It demonstrates the export of four countries to the UAE (Figure 2).

When analysing individual areas and the most significant sectors, it should be emphasized that all partners expressed their readiness to deepen cooperation in the field of new technology and innovation. For the UAE, Estonia is a relevant partner in the IT sector. The UAE wants to cooperate in building an innovative future, especially in creative cooperation on smart cities. Moreover, the UAE, as a leader in the development of AI in the Middle East, has established close cooperation in this area with Estonia. Lithuania, on the other hand, offered the UAE cooperation in the field of lasers. Moreover, both sides expressed interest in innovative solutions in biotechnology, electronics, and InfoTech, logistics, telecommunications. Latvia and the UAE emphasized that they should develop cooperation in ICT. Latvia and the UAE undertook to adopt an economic strategy, with particular attention to investments in agriculture, especially in the wood industry and tourism; logistics, especially investments in civil aviation; as well as investments in healthcare, and primarily in pharmacology. On the other hand, Lithuania is a significant country for the UAE in terms of its food security strategy. Therefore, both sides expressed their readiness to dynamize the investment and trade cooperation in agricultural products. Moreover, both partners have committed themselves to work together in the field of renewable energy. In this context, Lithuania has offered to sell its production of solar panels. Also, it should be underlined that all three Baltic states, together with the UAE, have declared their readiness to boost trade. In the area of security and defence, it was primarily the UAE that decided to deepen relations with Lithuania in combating terrorism and extremism. On the other hand, Estonia and the UAE agreed to conduct intensive cooperation in the field of cyber defence. From the UAE's perspective, the root of creative relations is searching for new allies in Central and Eastern Europe. It is significant for searching for new projects of new technologies and expanding partners in ensuring food security. From the Baltic states' perspective, the impetus for creative cooperation is the dynamizing of foreign investments. Moreover, the need to increase the number of markets for selling food products is crucial. Due to the nature of the UAE, the increase in 
the dynamics of visits at the highest level will naturally contribute to both increased investments in the Baltic region as part of 3SI projects and will open new creative opportunities for economic expansion and export of products not only on the UAE market but also through them, as a trade hub, as well as to the Asian and African markets. Additionally, the UAE has taken strategic choices related to close political and military cooperation, both with the US and European partners, including NATO. Therefore, this country is also a natural ally for making the 3SI a significant element of a broader world strategy in line with the newly emerging global order is coming.

However, if Estonia, Latvia, and Lithuania want to be an influential part of 3SI regarding the Middle East, including the UAE, these states must be creatively active in this country. Critically evaluating and comparing the three Baltic states, it should be noted that so far only Lithuania has no diplomatic representation in the UAE. It is essential to maintain and boost relations with this country. This is especially important due to the cultural and social aspects for which the direct presence and contacts in the UAE provide the opportunity for creative, mutually beneficial relations. Moreover, in the context of the 3SI projects, the UAE is of particular importance for Lithuania. Recently the UAE's company from Dubai DP World has become the majority shareholder of the strategic TransInvestService of Yuzhne port, in Odesa in Ukraine. This port will be associated with the 3SI infrastructure. Consequently, it will connect with the Port of Klaipeda in Lithuania. Moreover, DP World company is one of the biggest global trade enablers. This, in turn, provides other opportunities for closer cooperation between the UAE and Lithuania, as well as Latvia and Estonia.

\section{Conclusions}

On 1 May 2004, at the same time, Estonia, Latvia, Lithuania joined the EU. Before this date, and in the first years after accession, these states foreign and security policy focused on European integration. However, the events in the Middle East at that time and the ambitions of these countries to play a more significant role in the global arena led to greater interest in MENA. On the other hand, the 3SI announced in 2015, opened new opportunities for twelve countries, in most countries from the former Eastern Bloc, located between the Baltic Sea, the Adriatic Sea, and the Black Sea, not only to influence EU institutions, but also its neighbourhood, including the Middle East. The Baltic states should creatively see the new opportunities that the UAE-US-Israel agreement brings. Therefore, the 3SI projects should include the UAE as a trade and economic hub with a great experience. In addition, $D P$ World, a Dubai-based company, manages Constanta South Container Terminal, a strategic Romanian seaport in Constanta on the Black Sea, close to the Via Carpathia project connecting with the strategic seaport of Klaipeda on the Baltic Sea, in Lithuania. Moreover, in March, 2019 this Emirati company has received a renewal of the concession for the next 30 years, i.e., until 2049. In this sense, the UAE implementing ambitious plans and development strategies and as an ally with the transatlantic area and an active player on the international arena, including building close relations with Israel, should be a valuable partner for the 3SI and the states of the Baltic region. The World fair Expo 2020 in Dubai (October, 2021 to March, 2022) is a huge opportunity to present both joint projects within 3SI, and the Baltic 
states. Moreover, it should be noted that if the Baltic states are stronger outside the EU, having strong alliances, such as with the UAE, their position within the EU will surely increase.

As a recommendation on how to use diplomacy creatively in the future, the author suggests organizing during Expo 2020 (from October, 2021 till March, 2022) joint events to promote all three Baltic states' opportunities. Moreover, there should be collective activities within a larger platform, i.e., the 3SI. Dubai has an ambitious and creative plan to establish a new business centre, in place of the exhibition area. Therefore, Estonia, Latvia, and Lithuania with other 3SI states should set up a joint initiative with an appropriate team to promote 3SI countries and establish partnerships for cooperative projects. Moreover, Lithuania should open an Embassy in the UAE as soon as possible. Then, it should become the creative tool of its diplomacy.

The carried-out research, and the author's personal experience, indicate that apart from adopted initiatives, strategies, and plans, the crucial issue is the creative involvement of diplomats. Especially in contemporary international relations, where programs do not keep up with the changing constellation of interests, only the creativity of diplomats, understanding both the interests of their own country and the changing world, can contribute to constructing an effective global cooperation platform.

\section{References}

Ave Tampere: Government Communication Unit. (2015). Estonia and Dubai signed a Memorandum of Cooperation on e-governance and ICT. Vabariigi Valitsus. https://www.valitsus.ee/en/news/estoniaand-dubai-signed-memorandum-cooperation-e-governance-and-ict

Baba, G., \& Kaya, T. O. (2014). Testing the creativity of Kevin Rudd's middle power diplomacy: EU-Australia partnership framework versus the Asia-Pacific community. International Relations of the Asia-Pacific, 14(2), 239-269. https://doi.org/10.1093/irap/lct025

Breitbart. (2014). Abdullah bin Zayed, Latvian counterpart, discuss boosting bilateral cooperation. https://www.breitbart.com/news/upi20140319-202510-4447/

Breuning, M. (2007). Foreign policy analysis: A comparative introduction. Palgrave Macmillan. https://doi.org/10.1057/9780230609242

Broka, S. (2021). Latvia in the Middle East: Between pragmatism and challenges. In A. Sprūds \& S. Broka (Eds.), Latvian Foreign and Security Policy: Yearbook 2021 (pp. 165-176). Latvian Institute of International Affairs.

Council of the European Union. (2019). Council Conclusions on an EU Strategic Approach to International Cultural Relations and a Framework for Action (2019/C 192/04). Official Journal of the European Union, 6(7), 1-10.

Dubai Chamber. (2018). Latvian President affirms commitment to boost UAE Ties. AL Press. https://alpress.allouneh.com/index.php/en/gov-ngo/26-gov/15239-latvian-president-affirms-commitmentto-boost-uae-ties

Emirates News Agency. (2014). Abdullah bin Zayed, Lithuania FM discuss bilateral relations and latest developments in the region. http://wam.ae/en/details/1395266656985

Emirates News Agency. (2015a). Foreign Minister receives Latvian counterpart. http://wam.ae/en/details/1395281345682

Emirates News Agency. (2015b). UAE, Lithuania, discuss cooperation on food security. http://wam.ae/ en/details/1395276418355 
Emirates News Agency. (2016). UAE, Latvia sign economic cooperation deal. http://wam.ae/en/details/1395295215959

Evans, G., \& Grant, B. (1991). Australia's foreign relations in the world of the 1990s. Melbourne University Press.

Gerner, D. J. (1991). Foreign policy analysis: Renaissance, routine or rubbish. In W. Crotty (Ed.), Political science: Looking to the future. Vol. 2: Comparative politics, policy, and international relations (pp. 123-185). Northwestern University Press.

Gerner, D. J. (1995). The evolution of the study of foreign policy. In L. Neack, J. A. K. Hey, \& P. J. Haney (Eds.), Foreign policy analysis: Continuity and change in its second generation (pp. 17-32). PrenticeHall, Inc.

Government Communication Unit. (2019). Prime minister ratas: We hope to open a direct flight to Dubai soon. Vabariigi Valitsus. https://www.valitsus.ee/en/news/prime-minister-ratas-we-hopeopen-direct-flight-dubai-soon

Hudson, V. M. (2007). Foreign policy analysis: Classic and contemporary theory. Rowman \& Littlefield Publishers, Inc.

Hyndle-Hussein, J. (2020). Litwa: profil rządu Ingridy Šimonytė. Ośrodek Studiów Wschodnich. https:// www.osw.waw.pl/pl/publikacje/analizy/2020-12-16/litwa-profil-rzadu-ingridy-simonyte

Jakniūnaitè, D. (2018). No good end in sight: The crumbling Iran Nuclear deal. Lithuanian Foreign Policy Review, 37, 45-47.

Jung, B. (2014). Jak mierzyć kreatywność? Przegląd podejść i prób metodologicznych. In A. Zorska, M. Molęda-Zdziech, \& B. Jung (Red.), Kreatywność I innowacyjność w erze cyfrowej. Twórcza destrukcja 2, (pp. 61-76). Oficyna Wydawnicza Szkoła Główna Handlowa w Warszawie.

Katzenstein, P. J. (1985). Cornell studies in political economy. Small States in world markets: Industrial policy in Europe. P. J. Katzenstein (Ed.). Cornell University Press.

Kodabux, A. (2019). The future of IR lies in creativity rather than "New Thinking". In E-International Relations. https://www.e-ir.info/pdf/80509

Krzymowski, A. (2020a). Expo 2020 Dubai on the journey to achieve the United Arab Emirates' Soft Superpower. University of Sharjah Journal for Humanities and Social Sciences, 17(2A), 1-21. https://doi.org/10.36394/jhss/17/2A/13

Krzymowski, A. (2020b). Sustainable development goals in Arab Region - United Arab Emirates' case study. Problems of Sustainable Development, 15(1), 211-220. https://doi.org/10.35784/pe.2020.1.22

Krzymowski, A. (2020c). The European Union and the United Arab Emirates as civilian and soft powers engaged in sustainable development goals. Journal of International Studies, 13(3), 41-58. https://doi.org/10.14254/2071-8330.2020/13-3/3

Krzymowski, A. (2020d). The importance of Ukraine's political and economic relationship with the United Arab Emirates for the Lublin Triangle. Economic Annals-XXI: World Economy and International Economic Relations, 184(7-8), 16-28. https://doi.org/10.21003/ea.V184-02

Krzymowski, A. (2020e). The significance of the Black Sea countries of the three seas initiative relations with the United Arab Emirates. Online Journal Modelling the New Europe, 34, 86-105. https://doi.org/10.24193/OJMNE.2020.34.04

Lingevicius, J. (2020). Identity discourse within a geopolitical crisis: The case of Lithuania. POLITIKON: The IAPSS Journal of Political Science, 44, 26-43. https://doi.org/10.22151/politikon.44.2

Lsm.lv. (2017). President drums up business in Dubai. https://eng.lsm.lv/article/politics/president/president-drums-up-business-in-dubai.a225581/

Maigre, M. (2015). Estonia: In pursuit of a value-based foreign policy. In J. Forbrig (Ed.), Estonia: A region disunited? Central European responses to the Russia-Ukraine crisis (pp. 16-20). Europe Policy Paper 1. German Marshall Fund of the United States. 
Milevski, L. (2020). Latvia's new state defense concept. Foreign Policy Research Institute. https://www. fpri.org/article/2020/06/latvias-new-state-defense-concept/

Ministry of Foreign Affairs, Republic of Latvia. (2018). Latvia and the United Arab Emirates Agree on the Need for Convening a Bilateral Economic Council. https://www.mfa.gov.lv/en/news/latestnews/59924-latvia-and-theunited-arab-emirates-agree-on-the-need-for-convening-a-bilateraleconomic-council

Ministry of Foreign Affairs, Republic of Latvia. (2020). Latvia welcomes normalization of relations between the United Arab Emirates and the State of Israel. https://www.mfa.gov.lv/en/article/latviawelcomes-normalization-relations-between-united-arab-emirates-and-state-israel

Neack, L., Hey, J. A. K., \& Haney, P. J. (Eds.). (1995). Foreign policy analysis: Continuity and change in its second generation. Prentice-Hall, Inc.

Nekrašas, E. (2011). Refleksje Nad Litewską Polityką Zagraniczną. Politeja, 16, 79-94.

Paulauskas, A. (2004). Lithuania’s new foreign policy. Lithuanian Foreign Policy Review, 13-14, 7-16.

Potter, Ph. B. K. (2017). Methods of foreign policy analysis. International Studies Association and Oxford University Press. https://oxfordre.com/internationalstudies/view/10.1093/acrefore/9780190846626.001.0001/acrefore-9780190846626-e-34

Press Releases, Foreign Affairs Committee. (2020). Foreign Affairs Committee visit to Gulf countries focuses on parliamentary relations and business diplomacy. https://www.riigikogu.ee/en/press-releases/ foreign-affairs-committee-en/foreign-affairs-committee-visit-gulf-countries-focuses-parliamentaryrelations-business-diplomacy/

Press Service of the President. (2017). New opportunities open up for Lithuania in the Gulf. President of the Republic of Lithuania. https://www.lrp.lt/en/media-center/news/new-opportunities-open-upfor-lithuania-in-the-gulf/28741

Putnam, R. D. (1988). Diplomacy and domestic politics: The logic of two-level games. International Organization, 42(3), 427-460. https://doi.org/10.1017/S0020818300027697

Raik, K. (2020). Estonia in the UN Security Council: The importance and limits of European Cooperation. International Centre for Defence and Security.

Republic of Estonia, Ministry of Defence. (2017). Minister of Defence Margus Tsahkna introduces Estonia's defence industry in Abu Dhabi. https://kaitseministeerium.ee/en/news/minister-defencemargus-tsahkna-introduces-estonias-defence-industry-abu-dhabi

Republic of Estonia, Ministry of Foreign Affairs. (2020). The speech of Foreign Minister Urmas Reinsalu about Estonian foreign policy in Riigikogu. https://vm.ee/en/news/speech-foreign-minister-urmasreinsalu-about-estonian-foreign-policy-riigikogu

Rostoks, T. (2020). Global processes and Latvian foreign policy in 2019. In A. Sprūds \& S. Broka (Eds.), Latvian Foreign and Security Policy: Yearbook 2020 (pp. 33-43). Latvian Institute of International Affairs.

Rothenberg, A., \& Hausman, C. R. (1976). Introduction. In A. Rothenberg \& C. R. Hausman (Eds.), The creativity question (pp. 3-26). Duke University Press.

Salman, N. (2019. Exclusive: Estonian president says her country and UAE "can help other countries enter digital revolution". Emirates News Agency. https://www.wam.ae/en/details/1395302785467

Smith, S. (1983). Foreign policy analysis: British and American orientations and methodologies. Political Studies, 31(4), 556-565. https://doi.org/10.1111/j.1467-9248.1983.tb01353.x

Smith, S. (1986). Theories of foreign policy: An historical overview. Review of International Studies, 12(1), 13-29. https://doi.org/10.1017/S026021050011410X

Smith, S., Hadfield, A., \& Dunne, T. (2016). Introduction. In S. Smith, A. Hadfield \& T. Dunne (Eds.), Foreign policy: Theories, actors, cases (pp. 1-12). Oxford University Press. https://doi.org/10.1093/hepl/9780198708902.003.0030 
Snyder, R. C., Bruck, H. W., \& Sapin, B. (1962). Foreign policy decision-making: An approach to the study of international politics. Free Press of Glencoe.

Telecommunications and Digital Government Regulatory Authority. (2016). UAE and Estonia share best smart e-service practices exchange made during visit of UAE delegation. https://tdra.gov.ae/

The Baltic Course: International Magazine for Decision Makers. (2020). Estonia's Foreign Policy Development Plan until 2030 Unveiled. http://www.baltic-course.com/eng/analytics/?doc=155980

The President's Communication Group. (2021). The Foreign Policy Coordination Council discussed Lithuania's key objectives in foreign policy in 2021. President of the Republic of Lithuania. https:// www.lrp.lt/en/news/the-foreign-policy-coordination-council-discussed-lithuanias-key-objectivesin-foreign-policy-in-2021/35343

United Arab Emirates Ministry of Foreign Affairs. (2020). Lithuanian President hails relations with UAE. Press Arabia. https://pressarabia.qa/lithuanian-president-hails-relations-with-uae/?_cf_chl_jschl_ tk_=pmd_a522cf195e262b7219bd2cf44e4830aa06361d0e-1627919463-0-gqNtZGzNAg2jcnBszQii

United Arab Emirates Ministry of Foreign Affairs and International Cooperation. (2017). H. H. Sheikh Abdullah bin Zayed meets with Lithuanian Foreign Minister. https://www.mofaic.gov.ae/en/MediaHub/News/years/2017/7/12/12-07-2017-UAE-Lithuania2

United Arab Emirates Ministry of Foreign Affairs and International Cooperation. (2020). Lithuania FM Opens Embassy in Abu Dhabi. https://www.mofaic.gov.ae/en/MediaHub/News/2020/3/9/0903-2020-UAE-Lithuania

United Arab Emirates Ministry of Foreign Affairs and International Cooperation. (2016). UAE, Latvia Hold Second Round of Political Consultations in Riga. https://www.mofaic.gov.ae/en/MediaHub/ News/2016/10/15/15-10-2016-UAE-Rega

Vahtla, A. (2018). Tammist meets with UAE Minister of State, talks Expo, flights, IT Companies. Err.ee. https://news.err.ee/888652/tammist-meets-with-uae-minister-of-state-talks-expo-flights-it-companies

WAM, Alfaham, T., \& Aamir, M. (2019). Al Bowardi and Estonian Defence Minister Discuss Defence Cooperation. Emirates News Agency. https://wam.ae/en/details/1395302809186

WAM, \& Bashir, H. (2018). Al Mansouri meets Estonian PM. Emirates News Agency. http://wam.ae/ en/details/1395302686914

WAM, Salman, N., \& Bashir, H. (2017). Mohammed bin Rashid meets with Lithuania's President - Update. Emirates News Agency. http://wam.ae/en/details/1395302643287 